\title{
Buddhist Instruction Care for Thai Elderly in the Upper Northeast
}

\author{
Niraj Ruangsan ${ }^{1}$, Phrasophonphatthanabundit ${ }^{2}$, Vitthaya Thongdee ${ }^{3}$, Suraphon Promgun ${ }^{4}$, Wichian \\ Sanmee $^{5}$, Ekarach Kositpimanvach ${ }^{6}$ \\ ${ }^{1,3,4,6}$ Faculty of Education, Mahachulalongkornrajavidyalaya University \\ ${ }^{2}$ Faculty of Buddhism, Mahachulalongkornrajavidyalaya University, \\ ${ }^{5}$ Faculty of Humanities and Social Sciences, Khon Kaen University \\ ${ }^{1}$ pruan9301@uni.sydney.edu.au, ${ }^{2}$ niraj.rua@mcu.au.th, \\ 1 niraj_rs@outlook.com
}

\begin{abstract}
The paper aimed to clarify the Buddhist instruction care for planning Thai elderly to have well-being in the sociocultural settings concerning the elderly development project in Thailand. The objectives of this study were: 1) to clarify the management policy of the elderly development within the upper northeastern locale; 2) to discover conceivable thoughts of instruction care standards for the elderly through the principles of Buddhism, and 3) to create guidelines of Buddhist learning administration for planning the development of elderly well-being. The research methodology regarded the interpretive paradigm while the management of Buddhist learning was interpreted through participant observation, interviewing, focus-group discussion, and documentary investigation. The content analysis was performed to critically study the obtained data. In this research, there were 60 participants, including monks, elderly, government officials, community leaders, local philosophers, and villagers in Khon Kaen and Roi-et provinces. The findings indicate the Thai government policy provided the direction and budget allocation for developing the quality of life, welfare, and health of the elderly and also preparing younger generations to enter the elderly age. According to the document analysis and focus group discussion, it suggested the possible ideas of education care principles for the elderly through the Buddhist principles, particularly Bhavana 4. It also found that many projects have been organized for taking care of the elderly in collaboration with government agencies and communities. Those projects have been allocated budgets by the Thai government. The study suggested that Buddhist doctrine Bhavana 4 consisting of 1) physical development, 2) moral development, 3) mental development, and 4) intellectual development should be provided as the core content of the elderly's education care essentially affecting to the elderly life quality. The study indicates that the guidelines for Buddhist learning management for preparing elderly well-being, allowing the elderly to access the Bhavana 4 as it trains them to be endowed with Tisikkhā including moral discipline, mindfulness, and wisdom. Then, they could follow the Noble Eightfold Path that orients them to develop their well-being in Thailand's socio-cultural context
\end{abstract}

Index Terms

Elderly, Buddhist Education Care, Buddhist Principles, Thailand

Article Received: 10 August 2020, Revised: 25 October 2020, Accepted: 18 November 2020

\section{Introduction}

A tremendous association between education and health generally, and functional health, specifically, amongst older adults, has been properly documented in the USA and different developed countries for a long period of time [1] [2]. Although education does now no longer directly affect the function, studies at the link between socioeconomic status and health indicate numerous viable intervening mechanisms that could provide an explanation for the association [3]. For example, education will increase income potential, which permits better access to the best hospital therapy and consequently better treatment of health problems. It improves access to occupations that have higher running conditions. Education additionally improves healthassociated knowledge, which increases the understanding of disease processes and ends in healthier lifestyles, which includes having healthier diets, not smoking, not consuming excessively, receiving ordinary checkups and preventive care, and care regimens. Many extra psychological links have also been found, along with those regarding stress, control, and social support [4] [2]. In the last several years, there has been the study of the education-health association in old age, extended to several developing countries in Asia where populations are rapidly aging and as a consequence, the demand for health care resources by older populations are in need. Many studies generally found a positive association between the education and health of older adults in Thailand [5]. The current research takes place in Thailand and focuses on the associations between education and functional health of the elderly age as several social, economic, and cultural factors that make Thailand an interesting setting to test the generalizability of findings from previous studies. Moreover, Thailand has a great cultural diversity with some different ethnic groups and approximately eighty percent of the Buddhist population [6] [7]. To prepare people to enter the elderly age, Buddhism could be taken into account for the content of care for preparing Thai elderly to have well-being in Thailand's sociocultural context [8]. Because of the significance of its principles, Buddhist doctrine has been used to develop the well-being of Thai people. According to the National Strategy 2018-2037, it is a crucial element used in developing and strengthening human capital, which is one of the key essential factors to propel the country's development in every dimension to become a developed country, driven by wisdom and innovation [4].

\section{Research Objectives}

The research methodology involved the interpretive paradigm as it aimed to interpret what government and 
community staffs should do for education care for preparing Thai elderly to have well-being in the Thai sociocultural context. Also, this study aimed to answer the following research objectives:

1) to clarify the management policy of the elderly in the upper northeastern region;

2) to find possible ideas of education care principles for the elderly through the principles of Buddhism;

3 ) to develop guidelines of Buddhist learning management for preparing elderly well-being.

\section{Reserch methodology}

\section{Research Design}

This study was a Qualitative Research as a Field Study for obtaining concepts, principles, backgrounds, relation, and learning management in Buddhism of the elderly in the study area. The procedures were as follows:

1) Study and select a community which had a role in organizing activities in the Northeast by using Purposive Sampling,

2) Study and collect interviewing information by arranging the focus group with monks, community leaders, government officers, and elders,

3) Proceed with the synthesis of concepts, designs, and Buddhist learning management for elders focusing on the coordinative process of involved people in conducting this research,

4) Summarize and present the result of a field study by analyzing important issues: concepts, principles, backgrounds, designs, constructive procedures, and ways of learning management in Buddhism of elders aiming at its result to disseminate to a society which was each Provincial Office of Buddhism in the Northeast.

Area and Key Informants

1) The area of this study was to study temples and communities that organized Buddhist activities for the elderly in Khon Kaen and Roi-et provinces.

2) Key Informants were 60 people of a target group in Khon Kaen and Roi-et including 20 monks - snowball - selected from the monks who have a project about the elderly development; 20 elders who participate in the projects; 10 outstanding people in organizing projects such as community leaders, local philosophers, and villagers; 10 government officers in Khon Kaen and Roi-et provinces.

\section{Research Tools}

1) The research tools were as follows:

a) In-depth Interview Form, it was used to interview monks on status, role, concept, knowledge, and management of Buddhist learning for elders as well as the factors of barriers and successes in passing a body of knowledge in Buddhist learning management for elders.

b) Focus Groups Form, it was used to interrogate monks in status, role, concept, knowledge, and management of Buddhist learning for elders as well as the factors of barriers and successes in passing a body of knowledge in Buddhist learning management for elders. c) Observation Form, it was used to observe the fundamental information of the studied area in Khon Kaen and Roi-Et ran by Participatory Observation.

\section{Research Tools Development}

\section{a) Research Tools Construction}

1) Study documents, articles, related works in drug prevention and solution,

2) Construct an 'In-depth Interview Form' in accordance with the conceptual ideas and objectives.

3) Construct 'Focus Groups Form' in accordance with the conceptual ideas and objectives.

4) Construct 'Observation Form' in accordance with the conceptual ideas and objectives.

\section{b) Research Tools Verification}

1) Researchers submitted constructed tools to 3 experts to consider Content Validity.

2) Researchers consulted with research advisers with verified tools.

3) Researchers developed completed tools and continued data collection.

\section{Data Collection}

a) Preparation before proceeding with data collection

1) Ask for the official letter from Mahachulalongkornrajavidyalaya University, Khon Kaen Campus to inform objectives and benefits of the study to a target group,

2) Bring the record of Focus Groups Form to research assistants who were responsible for note-taking and informing the details of research conducts in this step.

b) Data collection of Fieldwork

1) Held the meeting with a target group to do selfintroduction and inform objectives of the study, and to ask for the coordination together with explaining the details in questioning,

2) Utilized the interview in data collection due to its flexibility in which there were two steps as follows:

2.1 In-depth Interview was used to continue the interview or face-to-face conversation. In so doing, the interview area was a peaceful place so that the interview would go on continuously with full of required details;

2.2 Focus Group Discussion was to collect the data to measure the knowledge, attitude, and behavior of humans as well as influential factors of behavior. The received answers were in line with considered reasons by the conversation group members. The questions were for gaining feeling, giving reasons, knowing motivations as well as the decisions and attitudes on occurrences or various things focused on giving opportunities to every member in a conversation group.

3) Utilized the Observation as a Participatory Observation and did fieldwork for data collection. There were two phases of the observation: Phase 1 was 'before conducting the research' and Phase 2 was 'during researching with data collection'. In the studied area along with the observation of way of life in the community was proceeded by Structures 
Observation, which was observing specified issues obviously and absolutely and recorded only specific issues.

\section{Data Analysis}

1) Analytical Induction: the researchers summarized the occurrences and several issues according to the involved questions.

2) Content Analysis: this was descriptive analysis, but it actually was to codify and summarize the data from documents and information technology as well as from Indepth Interview, Focus Groups, and Observation.

\section{Findings}

\section{Policies for Elderly Management}

The government policy primarily emphasizes the quality of life, welfare, and health of the elderly and preparing people to enter the elderly age as seen in the National Elderly Plan (NEP) implemented for more than 15 years. NEP is renewed as the National Elderly Plan No. 2 (2002-2021). In the 20Year National Economic and Social Development Plan and National Strategy (2017-2036), the policy on the elderly development operation is financially supported. The government policy now encourages the elderly to continue working and taking part in the labor market even if its proportion would be less or more dependent on the personal conditions of each elderly such as readiness and social supports. The policies could be separated into three levels as follows:

1) At the national level, the Department of Older Persons (DOP) established in 2006 works with the Office of Permanent Secretary of Ministry of Social Development and Human Security (MSDHS), responsible for inspiring old people to continue working or even finding opportunities to work. The strategic contingency plan has been obviously formulated for specifying goals and indicators by invited scholars and cooperated with top-down state agencies for the second period of the long-term elderly development.

2) At the ministry level, the main ministry providing service to the elderly is the Ministry of Public Health and Ministry of Social Development and Human Security. However, there is no mechanism to connect both ministries in the same workplace. Although there was a try to integrate plans among bureaus, it is in the beginning period.

3) At the operation level, provincial agencies developed the service according to a plan and support in academic supports from educational institutions. The law stipulates elders to have security, health care, social service, religious study, necessary information, career, self-development, social cooperative activity, facility, public service, and accommodations. Moreover, the elderly support fund was established to support the government mission and tax deduction is given to those who make donations or support the projects. However, there is no national older person committee responsible for implementing the provincial policy and plan and the number of officials responsible for the mission is inadequate.

In addition, the right for elderly is regulated in the Constitution of Thailand and the Elderly Person Act consists of several sections promoting security, life quality, welfare care, and fundamental service. The Department of Older Persons creates an elderly development manual in line with the Elderly Person Act 2003 to create public awareness of the elder important rights related to medical treatment, public health, education, religion, career, facility, residence, transportation fare reduction, and any other public service. Now, many policies, laws, and regulations for elders are created and inserted in the strategic plans of the Ministry of Labor, Ministry of Public Health, Ministry of Social Development and Human Security, Ministry of Defense, Ministry of Education, Ministry of Justice, Ministry of Tourism and Sports, Ministry of Culture, Ministry of Transport, and Ministry of Finance. Thus, it shows that Thailand gives great precedence to life quality development for elders. It is to say each agency tries to legislate as the tools to drive its mission. Also, those laws covered the Four Requisites in life: clothing, food, lodging, and medicine; and many ministries give the elders more privileges than those of younger people. The enactment of life quality for elders is worth, but its weakness appears in how elders could reach and understand the details of law for instance according to an announcement from Ministry of Social Development and Human Security on Regulation, Method and Condition for Security, Promotion, and Support in Funeral Management in 2004, 2,000 Baht is given to the elderly funeral management but many people do not know about this privilege even if it has been announced for 16 years.

In the upper northeastern region, according to the central policy, Khon Kaen and Roi-et responds to the policy by applying it as a service to many areas depending on the roles and duties of each agency. However, the main issue is to build self-reliance for the elderly and get them to live happily in society. The results of this research show that there are many agencies such as Khon Kaen Provincial Social Development and Human Security Office, Khon Kaen Social Welfare Development Center for Older Persons, the Sixth Academic Promotion and Support Office, Temples or Meditation Centers, Elderly School, Buddhist Club, and Department of Local Administration strongly follow the government policy in working process and this results in empirical success. In Khon Kaen and Roi-et, in both extended and single-family; a family is the most important unit in taking care of elders and the caregiver is a grandchild or family member. Although most elders in the research area could live by themselves, the family members still play an important role in taking care of them. However, for those who are alone, handicapped, and have no children, the government unit provides them caretaking. Anyhow, in a remote area, some of them cannot access to this service.

\section{Management and Buddhist Doctrines for the Elderly}

Based on the study, the management principles (POSDCORB) for the elderly development are as follows: 1) Planning, there is an operational plan with monthly meetings on providing facilities, food, transportation, organizing activities and co-operation with of different units. 2) Organization, there are designated organizations, segmentation and clearly defined duties. 3) Staffing, there are personnel from each of seven organizations in the research areas such as Khon Kaen Provincial Social Development and Human Security Office, Khon Kaen 
Social Welfare Development Center for Older Persons, the Sixth Academic Promotion and Support Office, Temples or Meditation Centers, Elderly School, Buddhist Club, and Department of Local Administration that conducted activities as planned. 4) Direction, all organizations have the supervisors to control the operations, and give orders; and there are leaders to command operations in coordination with other agencies. 5) Coordination, there is the ongoing collaboration between government agencies and communities. 6) Reporting, the operational results in both verbal and written forms are reported to the administrators and members of the organizations to realize the movement and progress of the mission. 7) Budget, for the main budget for the operation related to the elderly development, there are two sources of budget: government support and donation. Supported by the government, Khon Kaen Provincial Social Development and Human Security Office and Khon Kaen Social Welfare Development Center for Older Persons, the Sixth Academic Promotion and Support Office are the main agencies to administrate the elder development operation. Yet for the temples or meditation centers, elderly schools, Buddhist club, and Department of Local Administration are supported by donation or fund raising. For example, Ta Phra Sub-district Elderly School got the budget, 216,600 Baht, from Energy Regulatory Commission Service Area 4, and annually 100,000 Baht from Ta Phra Sub-district Administrative Organization.

In regards to the principles of Buddhism for the elderly development, the doctrine called 'Bhāvanā 4 (Development)' is significantly used in the operation. That is, 1) in terms of the physical development called 'kāya bhāvanā', it is the development of the body to be healthy and most importantly a relationship with the physical environment. 2) Moral development called 'sīla bhāvanā' is the development of morality of the elders to have betterment of behaviors and conducts. 3) Mental development or 'citta bhāvanā' is to develop the mind to have good qualities such as positive thinking and consciousness. 4) Intellectual development or 'paññā bhāvanā' is the intellectual development to have knowledge and understanding of reality and to perceive the natural laws of all arisen things.

Guideline of Buddhist Learning Management for Elderly Well-being

The focus group and document analysis suggested the guidelines of Buddhist learning management for preparing elderly well-being. They suggested that the elders need to follow the Noble Eightfold Path which is the 'core teaching' of Buddhism. Then, they could access the Bhavana 4 [9] as mentioned above. In order to educate the elders to practice Bhāvanā 4 and follow the Noble Eightfold Path, they need to understand the concepts of the Threefold Training (Tisikkhā) [9] including Moral Discipline (Silā), Mindfulness (Samādhi), and Wisdom (Paññā) as follows.

1) Moral Discipline is a learning process in Buddhism elders could follow to develop the ways to control their behaviors, create human relationship, self-adaptation in communities, society and environment.

2) Mindfulness is a mental training process of good mind. It is to train subconsciousness, necessary in working. The elders train their mind to avoid bad deeds and evil thoughts.

3) Wisdom is a learning process to have the right knowledge caused by the right viewpoint, belief and thoughts. Wisdom is the mind and awareness controller so that man who kept on it would see the reality of things.

\section{Recommendation}

The recommendations on the Buddhist education care of the elderly in the upper northeastern region are as follows:

1) Policy Level: According to the research result, the policies of the government should be declared to the elders through various channels. In regards to the proportion of elders' works, it should be seriously considered as it has to suit personal conditions of the elderly. Therefore, all parties should promote enhancement of life quality of the elders in response to the government policies.

2) Application of Research Results: Noble Eightfold Path, Bhāvanā 4 and Tisikkhā should be used to develop and create the moral training project for the elderly quality of life development. The manual of this training project should be published and used to organize the project in other regions.

3) Future Research: Future research should study on an administration of Buddhist curriculum that is proper to development of elders' lives; an innovation for enhancing Buddhist learning for elders.

\section{References}

[1] Elo, I.T., Preston, S. H. , Educational differentials in morality: United States. Social Science \& Medicine, 1995. 42 (1): p. 47-57.

[2] Agthong, R., The Effectiveness of Health Education Program of Self-Care Behaviors of the Hypertensive Elderly in the Community of Municipality. Region 4-5 Medical Journal, 2008. 27(2.2): p. 742754.

[3] Goldman, D., Smith, J. P., Socioeconomic differences in the adoption of new medical technologies. American Economic Review, 2005. 95(2): p. 234-237.

[4] Office of the National Economic and Socail Development Council. National Strategy. 2020 [cited 2020 22/10/2020]; Available http://nscr.nesdb.go.th/wpcontent/uploads/2019/10/NationalStrategy-Eng-Final-25-OCT-2019.pdf.

[5] Zimmer, Z., Amornsirisomboon, P. , Socioeconomic status and health among older adults in Thailand: An examination using multiple indicators. Social Science \& Medicine, 2000. 52(8): p. 1297-1311. 
[6] Potential Development of Sangha in Region 1. Journal of MCU Social Science Review, 2020. 9(3): p. 1-13.

[7] State Audit Office of the Kingdom of Thailand. Audite of the 2nd National Elderly Plan (2002-2021). 2020 [cited 2020 14/11/2020]; Available from: https://www.audit.go.th.

[8] Orathaya Saramart, Soamshine Boonyananta, Art-based Using to Develop Well-being of Older Adults: the Systematic Review. Journal of Graduate Studies in Northern Rajabhat Universities, 2019. 9(2): p. 17-32.

[9] Payutto, P.A., Dictionary of Buddhism. 2002, Sahadhammika Press: Bangkok 